\title{
Improving the quality of the railway transportation process
}

\author{
Viktor V. Kondratiev ${ }^{1, *}$, Viktoriya A. Olentsevich ${ }^{2}$, Boris $O$. Kuznetsov $^{2}$, and Antonina I. Karlina ${ }^{1}$ \\ ${ }^{1}$ Irkutsk National Research Technical University, 83, Lermontov Str., Irkutsk, Russia \\ ${ }^{2}$ Irkutsk State Transport University, 15, Chernyshevsky Str., Irkutsk, Russia
}

\begin{abstract}
The safety of trains is the basis of the efficient operation of the railway transport system, the optimal organization of passengers and cargo transportation. All organizational and technical activities in railway transport must meet the requirements of safe and uninterrupted train traffic. Traffic safety is ensured by the maintenance of all facilities, railway tracks, rolling stock, equipment and mechanisms, technical devices and communications. In order to ensure a given level of train safety, it is essential that the technical facilities and personnel have the appropriate safety level. Comprehensive management of reliability, risks, cost of life cycle in railways is a technology that improves the quality of services. This technology is characterized by several components, namely, factors that affect the reliability and safety of railway facilities, as well as the means of achieving reliability and safety; risk and complete safety; cost of life cycle. As part of the security provision, the Russian Railways regularly upgrades its fixed assets. These are projects related to safety, which are based on life safety aimed at ensuring the technological sustainability of the production process, improving traffic safety and maintaining the existing throughput capacity of transport infrastructure. The assessment of the influence of technical failures and defects on the performance and economic criteria of rail transport will enable objective management decisions to be made in the area of fixed assets renewal in order to improve traffic safety and to introduce measures to reduce the share of non-productive expenditures of structural units.
\end{abstract}

Keywords: transport process, quality of transport services, technical equipment, transport infrastructure, non-productive expenditures, traffic safety.

\section{Introduction}

Competitiveness of transport services in the railway sector largely reflects the quality of transport services, which in turn is formed by the implementation of the following key indicators of the industry: train speed, cargo delivery time, cargo safety, the degree of satisfaction with the transport of goods of various volumes, the timeliness of technological operations, the regularity and rhythm of keeping the cargo moving according to the established plan of delivery of manufactured products, the complexity of transport services, the level of transport and logical services provided, etc. The values of the presented performance indicators of the railway transportation system (RTS), which fully form the quality of transport services, largely depend on the level of performance indicators of operational work presented in Figure 1. Operational work can be represented as a set of the following main indicators: technical reliability of transport infrastructure and technical equipment, transportation process organization safety, the degree of efficiency of using rolling stock in terms of time, the degree of efficiency of using rolling stock in terms of power, the degree of efficiency of using rolling stock in terms of loadcarrying capacity. The same category includes nonproductive rolling stock performance, as well as quality indicators of its use $[2,8,14]$.

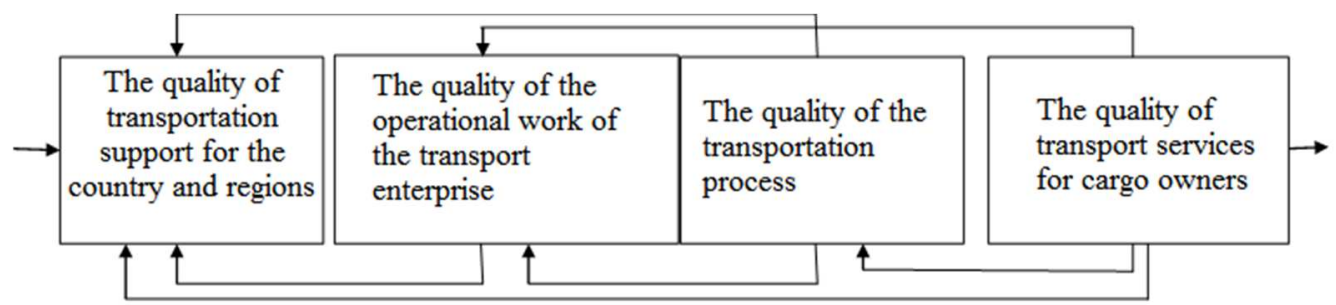

Figure 1 . The scheme of transport service quality indicators of the railway transport system

\footnotetext{
Corresponding author:kvv@istu.edu
} 
The technical condition and reliability of the transport infrastructure and equipment have a significant impact on the performance of the operational targets of all structural units of the railway transportation system. Maintaining a high level of condition, health and reliability of the infrastructure is the main task of the Russian Railways company, as it is with these fixed assets that the entire amount of transport activities is implemented. This policy makes it possible to increase the interest and responsibility of the company and its structural units for the proper fulfillment of the obligations undertaken to carry out transportation by using infrastructure facilities in accordance with the technological and technical purpose; to ensure an acceptable level of wear and tear; to timely repair, maintain and replace individual elements; to carry out updates and modernization in accordance with up-to- date requirements for the quality of transportation of goods and passengers; to ensure the safety of train traffic, excluding or minimizing all possible types of risks $[4,9,19]$.

To achieve the set objectives, within the territorial branches of Russian Railways OAO there is an infrastructure directorate, whose activities allow combining a number of separate types of railway transportation operations into a single system: track facilities, automation and telemechanics facilities, and operational degree of detail of the rolling stock. This infrastructure system operates within the existing structure of Russian Railways OAO Holding and is a large subdivision of the company, which defines its technical equipment performance indicators for each facility of the directorate (table 1).

Table 1. Indicators of performance evaluation of technical equipment of the infrastructure directorate

\begin{tabular}{|c|c|c|}
\hline $\begin{array}{c}\begin{array}{c}\text { Infrastructure directorate } \\
\text { service }\end{array} \\
\end{array}$ & Evaluation criteria & Indicators \\
\hline \multirow[t]{4}{*}{$\begin{array}{l}\text { Automation and telemechanics } \\
\text { service }\end{array}$} & $\begin{array}{l}\text { A volumetric indicator of the automation and } \\
\text { telemechanics service operation }\end{array}$ & Number of failures $\left(\mathrm{N}_{\text {fail }}\right)$ \\
\hline & $\begin{array}{l}\text { Natural indicators for evaluating the operation } \\
\text { of technical equipment for the automation and } \\
\text { telemechanics service }\end{array}$ & $\begin{array}{l}\text { Availability factor }\left(\kappa_{\mathrm{a}}\right) \text {, } \\
\text { Failure intensity }\left(\lambda_{\text {fail }}\right) \\
\text { Recovery time }(\mathrm{Tr})\end{array}$ \\
\hline & $\begin{array}{l}\text { An indicator of the automation and } \\
\text { telemechanics service operation }\end{array}$ & Score evaluation of the operation (B) \\
\hline & $\begin{array}{l}\text { Economic criteria for evaluating the } \\
\text { automation and telemechanics service } \\
\text { operation }\end{array}$ & $\begin{array}{l}\text { Economic consequences of technical } \\
\text { equipment failures }\left(\mathrm{EC}_{\text {fail }}\right)\end{array}$ \\
\hline \multirow[t]{4}{*}{ Track service } & $\begin{array}{l}\text { Volumetric indicator of the track service } \\
\text { operation }\end{array}$ & Number of failures $\left(\mathrm{N}_{\text {fail }}\right)$ \\
\hline & $\begin{array}{l}\text { Natural indicators for evaluating the operation } \\
\text { of technical equipment for the track service }\end{array}$ & $\begin{array}{l}\text { Failure rate } \lambda_{\text {fail }} \text { and time to eliminate the } \\
\text { consequences of failures }\end{array}$ \\
\hline & A track service quality indicator & Score evaluation of the track state (B) \\
\hline & $\begin{array}{l}\text { Economic criteria for evaluating the track } \\
\text { service operation }\end{array}$ & $\begin{array}{l}\text { Economic consequences of technical } \\
\text { equipment failures }\left(\mathrm{EC}_{\text {fail }}\right)\end{array}$ \\
\hline \multirow[t]{4}{*}{ Rolling stock service } & $\begin{array}{l}\text { Volumetric indicator of the rolling stock } \\
\text { service operation }\end{array}$ & Number of failures $\left(\mathrm{N}_{\mathrm{fail}}\right)$ \\
\hline & $\begin{array}{l}\text { Natural performance indicators for evaluating } \\
\text { the operation of the rolling stock service } \\
\text { technical equipment }\end{array}$ & $\begin{array}{l}\text { Failure rate } \lambda_{\text {fail }} \text { and time to eliminate the } \\
\text { consequences of failures }\end{array}$ \\
\hline & $\begin{array}{l}\text { An indicator of the rolling stock operation } \\
\text { quality }\end{array}$ & $\begin{array}{l}\text { Corresponding to the target indicators in } \\
\text { terms of technical equipment failures }\end{array}$ \\
\hline & $\begin{array}{l}\text { Economic criteria for evaluating the rolling } \\
\text { stock operation }\end{array}$ & $\begin{array}{l}\text { Economic consequences of technical } \\
\left.\text { equipment failures ( } \mathrm{EC}_{\text {fail }}\right)\end{array}$ \\
\hline
\end{tabular}

Analysis of Table 1 shows that it is difficult to single out one main indicator, allowing one to significantly evaluate the activities of all the structural units of the infrastructure system of railway transportation, since its production, commercial, financial and economic activities have a complex structure. However, it should be noted that the main tasks of the railway transportation system to meet the indicators that characterize the failsafety, rhythm and safety of the services provided by the infrastructure, namely, the number of events that caused train safety violations, the number and intensity of failures of technical equipment of the infrastructure. Still, the specific place of this system is held by indicators that characterize the safety of the transportation process, fail-safety, the regularity and rhythm of the maintenance of the infrastructure, the number and intensity of technical equipment failures. In connection with these factors, it is advisable to conduct a study in the railway transportation system by the example of the operation of the automation and telemechanics sector. Ensuring the reliability of the operation of signaling, centralization and blocking devices largely leads to the maintenance of high levels of train safety, smoothness and timeliness of production of technological operations. The implementation of the full schedule of trains and daily schedules of railway stations ensures the optimal operation of all the structural units of the railway transportation system. It also affects most of the industry's financial and economic performance, such as: productivity, non-productive expenditures of transport companies and service users, operating costs, freight costs, as "technical equipment failure" indicators 
and the quality of production and technical processes are in direct relationship and affect the performance and functioning indicators of all transport enterprises of the railway transportation system $[3,5,6]$.

According to the maintenance procedures of transport infrastructure and equipment established in the railway transportation system, the qualitative characteristics of technical maintenance of devices of automation and telemechanics are reflected in the scoring evaluation of their condition and performance, taking into account the reliability of their operation. The technical means that provide the transportation process are characterized by reliability indicators, which in turn should have the properties of fail-safety, durability, repairability.

In accordance with the goals and objectives set by Russian Railways OAO, all the structural subdivisions included in the sector of automation and telemechanics are required to provide functions aimed at:

- involving the maintenance of means of railway automation and telemechanics in a technically sound state within the established boundaries of production activities;

- preventing and eliminating violations of their normal operation in accordance with the regulatory legal acts of the Russian Federation, the regulations of Russian Railways OAO (RZD OAO) and the railway;

- ensuring the safety of train traffic and performing shunting operations at the objects of railway transportation system;

- implementation of measures aimed at improving the reliability and continuity of operation of the means of large-scale railway automation and telemechanics, efficiency of their functioning and economy of their operation.

\section{Problem Statement}

Organization traffic safety is ensured by the maintenance of all objects, railways, rolling stock, equipment and mechanisms, technical devices and communications.

\section{Research Questions}

Methods of organization traffic safety is ensured by the maintenance of all objects, railways, rolling stock, equipment and mechanisms, technical devices and communications.

Economic efficiency of maintenance of facilities, railways, rolling stock, equipment and mechanisms, technical devices and communications.

1. Research of failures of technical means of the railway transportation system. As practice shows, it is the failures of the infrastructure system elements and the technical means responsible for ensuring the transportation process that have the maximum impact on the safety of trains in the railway station, which is the main indicator of the quality of the transportation process, in particular, the indicator of the quality of transportation services $[1,13,16]$.
As a result of the failure of infrastructure system and technical equipment elements, malfunctions in their operation, impairment of their performance, there are non-scheduled detention of cargo and passenger trains, leading to an increase in the cargo delivery, as well as an increase in operating costs and an growth of the cost of the transportation process, since additional labor and material resources will be used to eliminate them. There is also a possibility of an increase in the risk of loss of existing users of the services of the railway transportation system and a decrease in the likelihood of attracting new ones. This is a result of their transition to road transport as the most attractive one for the organization of the transportation process, which will lead to the loss of potential revenues of Russian Railways OAO, a decrease in its level of competitiveness.

From an economic point of view, the failure of an element of the infrastructure system and technical equipment is non-productive losses of the railway transportation system, arising from the inconsistency of the regulatory parameters of the transportation process to the actually established ones. These economic losses resulting from failure are divided into two categories: direct and indirect losses. Figure 2 shows the constituents of the costs.

The economic damage of the railway transportation system operation caused by the unproductive loss of transportation process time is primarily due to an increase in the share of the costs in terms of train-hours of non-scheduled detention of cargo, suburban and passenger trains. The amount of these expenditures is determined by the method of expenditure rates [15]. The cost estimate of the expenditures associated with delays of trains of corresponding categories due to the equipment failure is defined as a product of the delay time of the transportation process and the increased expenditure rate:

$\sum \mathrm{E}=\Delta \mathrm{Nt}_{\text {car }} * \mathrm{e}_{\text {car }}^{N t}+\Delta \mathrm{Nt}_{\text {pass }} * \mathrm{e}_{\text {pass }}^{N t}+\Delta \mathrm{Nt}_{\text {sub }} * \mathrm{e}_{\text {sub }}^{N t}$,

where $\Delta \mathrm{Nt}_{\mathrm{car}}$ is the train-hours of delays of cargo trains caused by failures of infrastructure system and technical equipment elements, failures in their operation, impairment of their serviceability in the relevant subdivision of Russian Railways OAO;

$\Delta \mathrm{Nt}_{\text {pass }}$ is the train-hours of delays of passenger trains caused by failures of infrastructure system and technical equipment elements, failures in their operation, impairment of their serviceability in the relevant subdivision of Russian Railways OAO;

$\Delta \mathrm{Nt}_{\text {sub }}$ is the train-hours of delays of suburban electric trains caused by failures of infrastructure system and technical equipment elements, failures in their operation, impairment of their serviceability in the relevant subdivision of Russian Railways OAO;

$\mathrm{e}_{\text {car }}^{N t}, \mathrm{e}_{\text {pass }}^{N t}, \mathrm{e}_{\text {sub }}^{N t}$ are the increased expenditure rate of a train-hour of the relevant category train detention, rubles. 


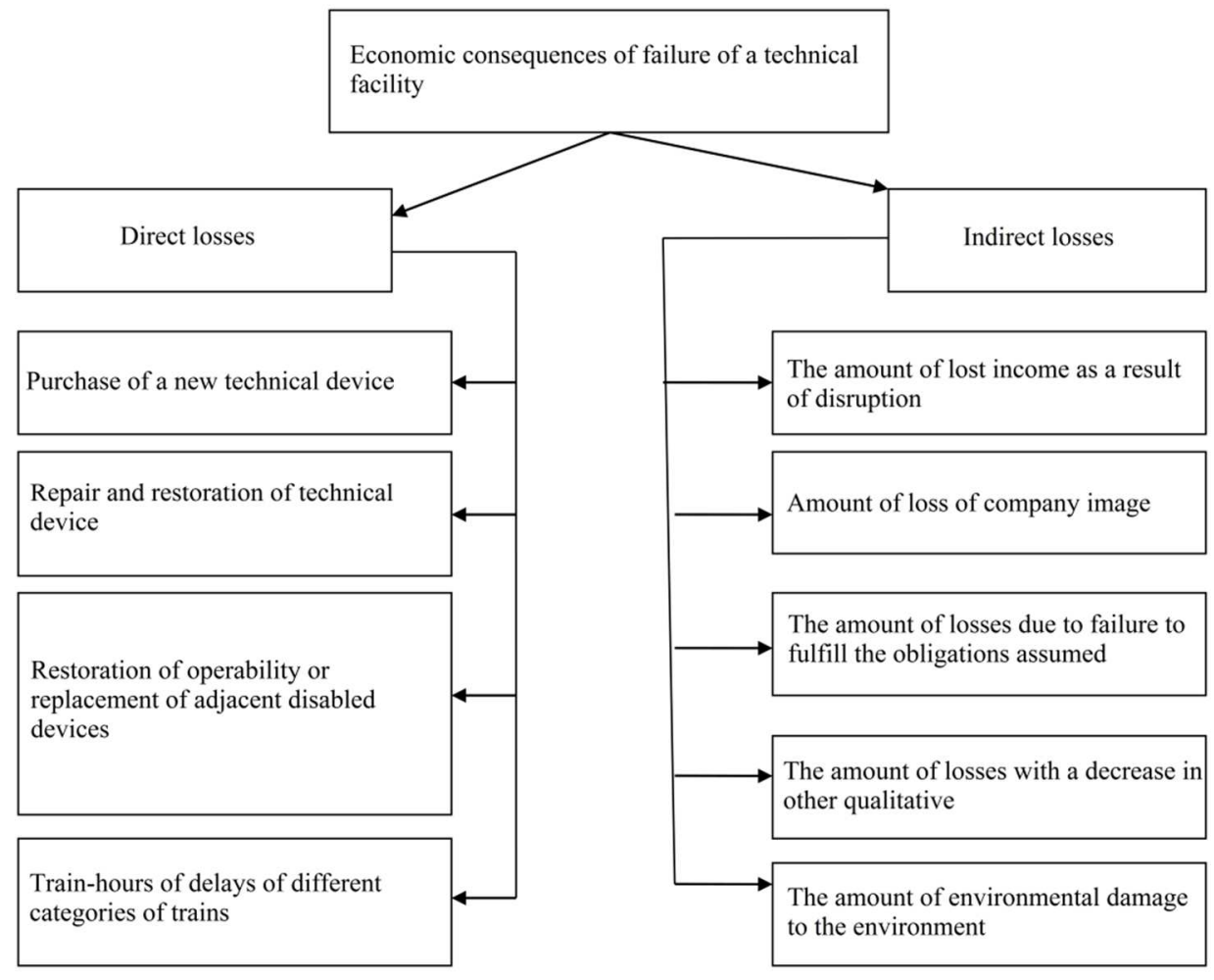

Figure 2. Economic losses resulting from the failure occurrence

Table 2 shows the calculation of the economic damage caused by the delay of trains of all categories of traffic, due to failures of infrastructure system and technical equipment elements, failures in their operation, impairment of their serviceability for 2019 in the Irkutsk division of signaling, centralization and blocking (an object of study).

Table 2. Economic damage caused by train delays in all categories of traffic due to failures of infrastructure system and technical equipment elements

\begin{tabular}{|l|c|c|c|}
\hline \multicolumn{1}{|c|}{$\begin{array}{c}\text { The name of the } \\
\text { meter }\end{array}$} & $\begin{array}{c}\text { Expend } \\
\text { able } \\
\text { rate, } \\
\text { rubles }\end{array}$ & $\begin{array}{c}\text { The } \\
\text { meter, } \\
\text { train- } \\
\text { hours }\end{array}$ & $\begin{array}{c}\text { Non- } \\
\text { productive } \\
\text { expenditur } \\
\text { es, rubles }\end{array}$ \\
\hline \multicolumn{3}{|c|}{ A type of activity - cargo transportation } \\
\hline $\begin{array}{l}\text { Train-hours of a cargo } \\
\text { train (electric traction) }\end{array}$ & 1884.05 & 256 & 482316.8 \\
\hline \multicolumn{4}{|c|}{ A type of activity - passenger transport } \\
\hline $\begin{array}{l}\text { Train-hours of a } \\
\text { passenger train in the } \\
\text { long-distance traffic }\end{array}$ & 368.06 & 56 & 20611.36 \\
\hline $\begin{array}{l}\text { Train-hours of a } \\
\text { passenger train in the } \\
\text { suburban traffic }\end{array}$ & 325.59 & 12 & 3907.08 \\
\hline Total economic damage & - & 324 & 506835.24 \\
\hline
\end{tabular}

2. According to the established technology of operation of the railway transportation system, the malfunction of infrastructure elements and technical equipment is taken into account using indicators such as events, failures and delays of trains, and the same indicators are classified as failures of the first, second and third groups. Events are understood to be malfunctions of technical equipment, which have caused serious violations of train traffic safety. Failure of technical equipment is understood to be a malfunction, which is an impairment of the object's serviceability. It is established that the period of elimination of the event should not exceed 12 hours, the period of elimination of the failure -2.5 hours and the period of elimination of the train delay -0.33 hours.

Taking into account the time factor and the severity of the consequences, in accordance with the "Regulations on the procedure for official investigation and registration of traffic accidents and other related to violation of traffic safety rules and operation of railway transport" [7, 18], depending on the duration of the break in the transportation production process, three categories of failures are distinguished:

- the first category includes failures that resulted in a delay of 6 minutes or more for a passenger or suburban train; for a delay of a cargo train at the station-to-station block (station) for an hour or more or led to cases of traffic safety violations in train service or shunting operation;

- the second category includes failures that led to a train delay at the station-to-station block (station) lasting from 6 minutes to 1 hour, or when the impact has led to a deterioration in performance, excluding delays of trains belonging to the first category;

- the third category includes failures that do not have consequences related to failures of the first and second categories.

A generalization of information about the failures that occurred during this year in comparison with the previous one and with an indication of the established reasons is provided in the "Analysis of the operation of the technical means of the division". The analysis 
showed that the maximum number of failures -82 - was made in 2018. The dynamics of quality indicators is presented in Table 3.

Table 3. Dynamics of quality indicators

\begin{tabular}{|l|c|c|c|}
\hline \multirow{2}{*}{\multicolumn{1}{|c|}{ Indicator }} & \multicolumn{3}{|c|}{ Period of time } \\
\cline { 2 - 4 } & $\mathbf{2 0 1 7}$ & $\mathbf{2 0 1 8}$ & $\mathbf{2 0 1 9}$ \\
\hline Failures, pc. & 54 & 82 & 70 \\
\hline Number of points, points & 5.2 & 3.34 & 3.92 \\
\hline
\end{tabular}

\section{Economic assessment of the possible consequences of a failure}

The economic assessment of the possible consequences of a failure of the infrastructure system and technical equipment, their malfunctions, disruptions in their performance predetermines the amount of capital expenditures and the priority of their investment. Table 4 , according to the category of the structural subdivision, presents an algorithm for evaluating its operation, depending on the amount of possible economic losses.

Table 4. Evaluation of the operation of the studied object depending on the magnitude of possible economic losses

\begin{tabular}{|c|c|c|c|}
\hline $\begin{array}{c}\text { A } \\
\text { categor } \\
\text { y of the } \\
\text { studied } \\
\text { object }\end{array}$ & $\begin{array}{c}\text { Reliability of } \\
\text { an } \\
\text { infrastructure } \\
\text { element or a } \\
\text { technical } \\
\text { equipment }\end{array}$ & $\begin{array}{c}\text { The flow of } \\
\text { technical } \\
\text { failures at a } \\
\text { division, } \\
\mathbf{1} / \mathbf{h}^{*} \mathbf{1 0}^{-\mathbf{n}}\end{array}$ & $\begin{array}{c}\text { Possible } \\
\text { economic } \\
\text { losses (per } \\
\text { month), } \\
\text { thousands of } \\
\text { rubles }\end{array}$ \\
\hline I & High degree & $10^{-5} \leq \lambda<10^{-3}$ & 50 \\
\hline II & Medium degree & $10^{-3} \leq \lambda<10^{-1}$ & $50-4000$ \\
\hline III & Low degree & $\lambda \geq 10^{-1}$ & $>4000$ \\
\hline
\end{tabular}

Ensuring a sufficiently high degree of reliability in the operation of infrastructure system and technical equipment elements minimizes the amount of possible economic damage in the organization of the transportation process. This strategy is the most preferable to the effective organization of the operation of the studied object $[10,12,17]$.

It is most appropriate to invest in the renovation of infrastructure system and technical equipment elements for the third category in terms of a studied object that has minimal reliability, and the economic damage to the performance indicators of the railway transportation system is significant and, along with that, may affect the continuity and safety of operation, lead to an increase in non-productive costs and a decrease in competitiveness.

Based on the data of Table 2 and 3, we calculated the magnitude of the intensity of failures of the infrastructure system and technical equipment elements $(\lambda)$ in terms of the studied object based on the average time of between failures $\left(T_{o}\right)$, by formulas $(2,3)$ :

$$
\begin{gathered}
\lambda=\frac{1}{T_{0}}, \\
\mathrm{~T}_{0}=\frac{365 * 24-\Delta \mathrm{Nt}}{n}
\end{gathered}
$$

where $\Delta \mathrm{Nt}$ is train-hours of non-scheduled delays of trains of different categories (table 2);

$\mathrm{n}$ is the number of failures of infrastructure system elements and technical equipment that caused train delays (table 3):

$\mathrm{T}_{0}=\frac{365 * 24-324}{70}=120,5$ hours.

Failure intensity in general in terms of the studied object:

$\lambda=\frac{1}{120,5}=8,29 * 10^{-3}$

\section{Research Methods}

In accordance with the evaluation parameters, the studied object falls to the first category, characterized by a low degree of reliability of the infrastructure system and technical equipment elements, as well as the high amount of economic damage arising from possible failures. The economic evaluation of the consequences of the failure of infrastructure system and technical equipment elements determines the size of capital contributions, priorities and the direction of their investment. In order to establish a priority range of investments in terms of the studied object, it is necessary to determine the proportion of economic damage $\left(\gamma_{\mathrm{ed}}\right)$, which will occur at the railway station and on the section of the railway track, in the overall amount of economic consequences of failures of infrastructure system and technical equipment elements. The priority range of investments in the renovation of elements of infrastructure system and technical equipment is presented in Table 5.

Table 5. The necessity to update the elements of the infrastructure system and technical equipment

\begin{tabular}{|c|c|}
\hline $\begin{array}{c}\text { The share of economic damage to the } \\
\text { railway station and the section of the } \\
\text { railway line of the studied object of } \\
\text { category III, \% }\end{array}$ & $\begin{array}{c}\text { The } \\
\text { investment } \\
\text { order }\end{array}$ \\
\hline$\gamma_{\mathrm{ed}}>60$ & $\begin{array}{c}\text { First order of } \\
\text { investment }\end{array}$ \\
\hline $40<\gamma_{\mathrm{ed}} \leq 60$ & $\begin{array}{c}\text { Second order } \\
\text { of investment }\end{array}$ \\
\hline$\gamma_{\mathrm{ed}} \leq 40$ & $\begin{array}{c}\text { Third order of } \\
\text { investment }\end{array}$ \\
\hline
\end{tabular}

According to Table 6, it is clear that if the proportion of economic damage to the railway station and the section of the category III railway line is more than 60 per cent of the total economic impact, the possibility of prior investment in the renovation of key elements of the infrastructure system and technical equipment at these railway stations and sections should be considered [11]. The algorithm of making managerial decisions to determine the order of updating the technical base of the subdivisions of automation and telemechanics facilities is presented in Figure 3. 


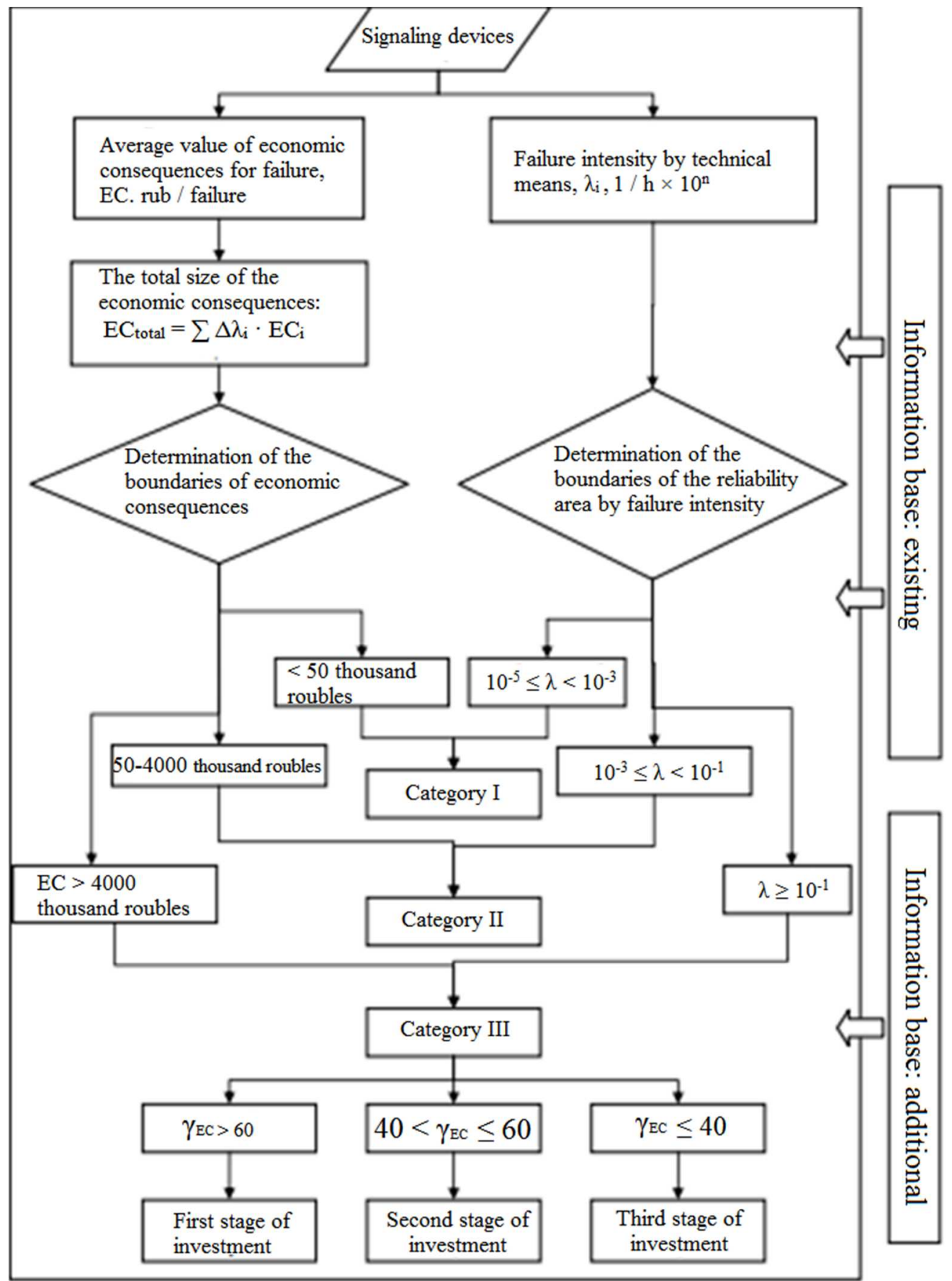

Figure 3. Algorithm for the order of managerial decision aimed at updating the technical base of the studied object]

\section{Findings}

Comprehensive management of reliability, risks, cost of life cycle in railways is a technology that improves the quality of services. This technology is characterized by several components, namely, factors that affect the reliability and safety of railway facilities, as well as the means of achieving reliability and safety; risk and complete safety; cost of life cycle. As part of the security provision, the Russian Railways regularly upgrades its fixed assets. These are projects related to safety, which are based on life safety aimed at ensuring the technological sustainability of the production process, improving traffic safety and maintaining the existing throughput capacity of transport infrastructure. The assessment of the influence of technical failures and defects on the performance and economic criteria of rail transport will enable objective management decisions to be made in the area of fixed assets renewal in order to improve traffic safety and to introduce measures to reduce the share of non-productive expenditures of structural units.

\section{Conclusion}

In the course of the completed study, the task to economically assess the effectiveness of quality management by the example of the subdivision of the infrastructure block of railway transport - the economy 
of automation and telemechanics - has been set and solved. The initial data for calculation are data on technical equipment failures. Taking into account economic losses in a structured form will allow one to demonstrate the real production situation in a particular subdivision or at the appropriate section of the signaling, centralization and blocking division. Assessment of the divisions of signaling, centralization and blocking, based on the principle of proportionality of economic consequences and parameters of reliability of technical means, will make it possible to determine the order of investment of the renovation of the company's fixed assets, affecting traffic safety. Possible economic damage, taking into account the parameters of the reliability of technical means, can be forecasted on any transport infrastructure object in the railway transportation system.

\section{References}

1. G.V. Bubnova. Freight marketing management models (Marshrut Publ., Moscow, 2003)

2. T.A. Bulokhova. More on the problem of improving the quality of transport services. Modern approaches to transport management and logistics. A coll. of mat. of the All-Rus. Sci. and Pract. Conf. (Moscow State Transp. Univ. Publ., Moscow, 2016)

3. T.A. Bulokhova. Modeling assessment of the quality of public transport services. Modern technol. Syst. Anal. Model., 1(65), 128-136 (2020)

4. T.A. Bulokhova, A.P. Bulokhov. Improving methodical approaches to assessing the quality of passenger transportation. Transport Infrastructure of the Siberian Region. Mat. of the 6th Int. Sci. and Pract. Conf., dedicated to the 40th anniversary of the found. of the Irkutsk State Transp. Univ., vol. 2 (IrGUPS Publ., Irkutsk, 2015), p. 62

5. S.S. Gromyshova, N.P. Astashkov, V.A. Olentsevich, O.V. Lobanov. Assessment of the level of safety of complex transport systems in order to increase their competitiveness in the transport service market. Modern technol. Syst. Anal. Model., 2(62), 250-259 (2019)

6. V.A. Makeev, E.E. Oksenyuk. Transport quality system: sequence of construction and evaluation of parameters. The Herald of RSTU, 2 (2013)

7. O.S. Maysak. SWOT analysis: object, factors, strategies. The problem of finding links between factors. Casp. Magaz.: manag. and high technol., 1 (2013)

8. V.A. Olentsevich, Y.I. Belogolov, G.N. Kramynina. Set of organizational, technical and reconstructive measures aimed at improvement of section performance indicators based on the study of systemic relations and regularities of functioning of railway transport system. IOP Conf. Ser. Mat. Sci. and Eng., 832, 012038 (2020)

9. Railway transport in Russia: challenges until 2025 (Institute of Natural Monopolies, 2019)
10. A.Yu. Ryazanov. Logical and mathematical representation of the work of transport and economic systems. Reliability and quality. Proc. of the Int. Symp., in 2 volumes (PSU Inform. Publ. Center, Penza, 2007), $406 \mathrm{p}$

11. G.V. Savitskaya. Analysis of the company's business activities, 2nd ed., update. and rev. (Ekoperspectiva SEP, Minsk, 1998)

12. M.O. Severova. Issues of assessing the efficiency of enterprises of railway transport infrastructure. Sci. probl. of transp. in Siber. and the Far East: an acad. J., 1, 24-26 (2011)

13. M.O. Severova, Yu.A. Shkudnova. On the issue of assessing the effectiveness of railway infrastructure. The Herald of Siber. State Transp. Univ., 26, 112-119 (2012)

14. L.V. Shkurin, S.V. Brazhnikova. Competitiveness of the transport company: economic assessment of the efficiency and quality of production activities of the structural units of railway transport, Monograph (Emperor Nicholas II Moscow State Transp. Univ. Publ., Moscow, 2016)

15. N.P. Tereshina, V.G. Galaburda, V.A. Tokarev et al. Economics of rail transport, Textbook (Ed. and Methodol. Center for Ed. in Railway Transp., Moscow, 2011).

16. The development strategy of the Federal Passenger Company until 2030. Report. Mat. Accord. to the techn. enquiry (2018)

17. V.D. Vereskun. Organizational and technological reliability and efficiency of functioning of railway production facilities (SSTU Publ., Novosibirsk, 2010)

18. A.A. Vovk. Assessment of the efficiency of transport production and reserves of its growth, Monograph (Kroma Publ., Moscow, 2000)

19. V.I. Yakunin. Infrastructure cannot be saved on if we want to create points of economic growth Gudok, 127, 3 (2010) 